\title{
sciendo
}

\section{SURVIVAL OF POLISH HOLSTEIN-FRIESIAN COWS TO SECOND, THIRD AND FOURTH LACTATION IN CONVENTIONAL AND AUTOMATIC MILKING SYSTEMS*}

\author{
Dariusz Piwczyński ${ }^{\star}$, Beata Sitkowska $^{1}$, Marcin Brzozowski ${ }^{1}$, Mariusz Bogucki², Piotr Wójcik ${ }^{3}$

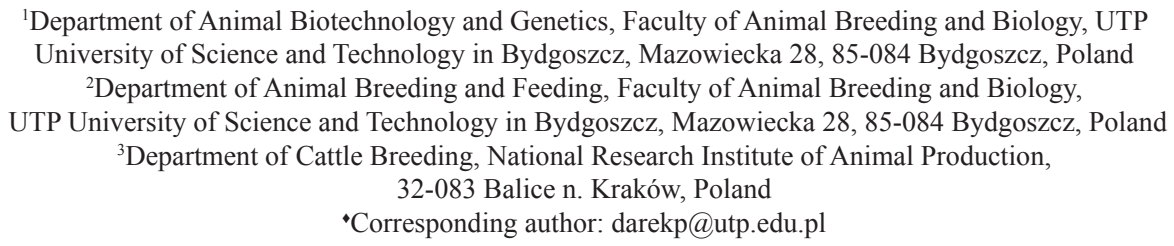

\begin{abstract}
The main objective of the study was to determine the effect of transition from a conventional milking system (CMS) to an automatic milking system (AMS) on survival of 6361 Polish Holstein-Friesian cows to second (SL2), third (SL3) and fourth (SL4) lactation as well culling reasons. The cows were born between 2002 and 2015 and calved between 2004 and 2018. All data for the survival analysis and culling reasons of cows in 17 herds during operation of CMS and AMS were extracted from the SYMLEK official milk recording system. Cow survival (SL2, SL3 and SL4) was analysed with multiple logistic regression using the following effects in the model: milking system (MS), first calving season (CS), age at first calving (AFC), ease of first calving (CE), birth of a dead calf at first calving (DC), milk yield (MY) for full first lactation (MY - this effect was ignored in SL2 analysis), herd $(H)$, and MS $\times H$ interaction. In the next stage of the study, $\chi^{2}$ test was used to analyse culling reasons of cows (udder diseases, low fertility - infertility and reproductive disorders, locomotor diseases, low milk yield, other diseases - metabolic, digestive and respiratory diseases, accidents and chance events) in the first, second and third lactation and collectively in the first three lactations. Logistic regression analysis indicated a significant effect of MS, AFC, DC on SL2 and SL3, and of MY on SL3 and SL4. Moreover, $H$ and MS $\times H$ interaction had a highly significant effect on SL2, SL3, and SL4. Cows used in AMS barns were characterized by significantly worse SL2 and SL3 compared to CMS (odds ratio), by $27.8 \%$ and $31.0 \%$, respectively. It was also observed that the effect of switching from CMS to AMS on cow survival was determined by herd membership - in most herds this effect was unfavourable. A distinctly positive effect of milking automation on cow survival (SL2, SL3, SL4) was noted in only one barn (herd) - it was a new barn with a considerably expanded number of milked cows, where the lying area was covered with straw. When analysing the reasons for culling in the first three lactations collectively, it was found that after the AMS system was introduced into the herds, there were increases in the rate of culling for locomotor diseases (by 0.85 percentage points (p.p.)), low milk yield (1.36 p.p.) and other diseases
\end{abstract}

\footnotetext{
*Work financed from: statutory activity BN-51/2019.
} 
(3.01 p.p.). It was also observed that the automation of milking reduced culling due to udder diseases by 0.37 p.p., low fertility by 3.24 p.p., and accidents and chance events by 1.60 p.p.

Key words: dairy cattle, survival, reasons for culling, automatic milking system

Research findings show that longevity is playing an increasing role in breeding programmes (PFHBiPM, 2020) because it has a significant effect on the profitability of dairy cattle breeding (Pelt et al., 2015). According to Sewalem et al. (2008), longevity is determined by breeder decisions, which are based on poor production, chance events, health, fertility, and others (e.g. milking speed, milking temperament, calving ease). In practice, environmental and economic factors (e.g. poor housing conditions, improper feeding, heat stress, low prices, herd management procedures) play a crucial role in herd survival and determine the productive lifespan of cows (Adamczyk et al., 2017). According to a review of De Vries and Marcondes (2020) the average productive lifespan of cows in highly productive herds is approximately 3 to 4 years.

Causes of culling from the herd (reasons for culling) have been of interest to many research groups (De Vliegher et al., 2012; Kern et al., 2016; De Vries and Marcondes, 2020). A review of the literature shows that as much as $90 \%$ of the cows leaves the herd due to reasons beyond the breeders' control (Orpin and Esslemont, 2010; Siatka et al., 2020). In view of the above facts presented by Orpin and Esslemont (2010), detailed analysis of culling reasons and levels is increasingly being utilized as a tool for proactive health planning in dairy herds.

The longevity of cows can be considered in various aspects according to its different definition (Sewalem et al., 2008; Zavadilová et al., 2011; Pelt et al., 2015). The idea of functional longevity was defined by Sewalem et al. (2008) as the number of days from first calving to culling, death, or censoring; adjusted for the effect of milk yield. A similar definition of productive life was provided by Vukasinovic et al. (1997), one difference being that they analyse numbers of months and not days, as can be found in the research of Sewalem et al. (2005). Zavadilová et al. (2011) uses a similar definition of functional longevity to length of productive life; it is the mean number of days between the first calving and culling. Pelt et al. (2015) defines productive life or lifespan as the time from first calving to the last test date for milk production before the animal was culled for slaughter (including dry periods). The idea of functional survival (length of productive life) was defined by Sewalem et al. (2005) as the number of days from first calving to next calving, death, or culling, and the record is censored if the cow has a next calving. In research by Shabalina et al. (2020) we can find two longevity definitions: length of productive life and stayability.

Statistical analysis of the cows' longevity traits, due to a different way of definition, requires the use of diverse statistical methods. These are most often the statistical techniques of survival analysis. In studies aimed to model survival to a given life stage (e.g. specific lactation), multiple logistic regression can be a useful tool for statistical data analysis (Reynen et al., 2015). Proportional hazards regression models are used to model length of productive life or length of life (measured in days), and also lifespan, enabling determination of culling risk in time " $t$ " in relation to the preceding period (Lubbers et al., 2000; Sewalem et al., 2005; Zavadilová et al., 2011). 
Numerous studies have shown that longevity traits are lowly heritable. Estimates of heritability for length of productive life ranged from 0.03 to 0.10 and for stayability from 0.01 to 0.06 . Pelt et al. (2015) estimated heritability for lifespan over the entire period of 72 months after first calving to range from 0.115 to 0.149 . ImbayarwoChikosi et al. (2017) investigated the genetic determinants of functional longevity and estimated the heritability at 0.11. In turn, Brotherstone et al. (1997) estimated heritability for completed lactations (third -0.084 , fourth -0.070 , fifth -0.030 ) and for lifespan (0.063). The same authors found a very strong genetic correlation for lifespan and survival to complete three (0.91), four (0.90) and five (0.95) lactations (Brotherstone et al., 1997). Due to the low heritability of longevity traits, of particular importance is to pinpoint the non-genetic sources of their variation, among which it is justifiable to consider a change of milking system.

Research findings indicate that among the existing milking systems, AMS barns provide cows with the greatest freedom of movement and freedom to be milked while preventing over-milking (Hopster et al., 2002). Yet on the other hand some cows exposed to the noises and sounds of the working AMS, may experience stress, leading to simultaneous decrease in milk yield and oxytocin secretion (Gygax et al., 2007). Tremblay et al. (2016) studied the differences between barns with conventional and automatic milking system and concluded that in both types it is possible to achieve high milk yield. In Poland, the first automated milking systems were installed around 10 years ago. Recent studies (Piwczyński et al., 2020) have shown that replacement of conventional milking with automatic milking in Poland may have a beneficial effect on increasing lactational milk yield and fertility traits of the cows. At the same time, considering the negative genetic correlations between milk yield traits and longevity traits (Imbayarwo-Chikosi et al., 2017), it is scientifically interesting to identify the consequences of implementing automatic milking in terms of cow survival.

The objective of the study was to analyse survival to second, third and fourth lactation and reasons for culling of Polish Holstein-Friesian (PHF) cows in barns equipped with conventional and later in automatic milking systems.

\section{Material and methods}

This study was based on survival information collected from 6361 Polish Holstein-Friesian (PHF) cows of Black-and-White variety that were born between 2002 and 2015 and calved between 2004 and 2018. The animals belonged to 17 herds located in Poland, where the climate conditions are similar and the barns, in which the cows were held, were equipped with free stalls and tie-stalls and the TMR feeding system (before AMS installation) and PMR feeding system (after AMS installation). In the years 2010-2013, these 17 herds changed the milking system from conventional (CMS) to automatic (AMS). One to four Lely Astronaut A4 robotic milkers (Lely Industries N.V., Maassluis, The Netherlands) were installed depending on the herd (Table 1). 


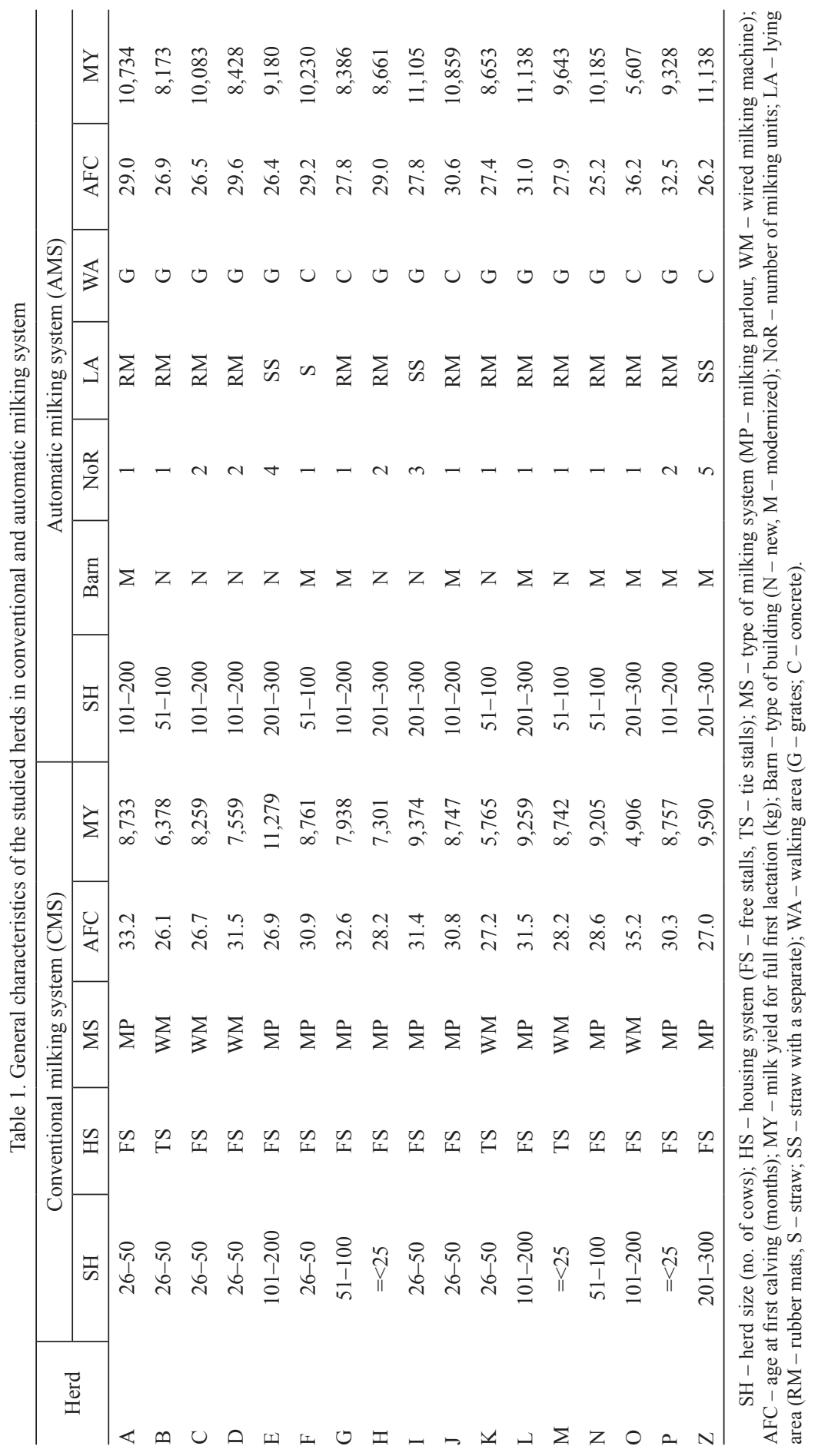




\section{Cows survival to second, third and fourth lactation}

In the first part of our research we analysed survival of the cows to the second (SL2), third (SL3) and fourth (SL4) lactations. Survival of the cows to the second, third or fourth lactation was assumed to be equivalent to second, third or fourth calving. The starting point for statistical analysis of SL3 and SL4 animals were primiparous cows that calved for the second time and had recorded milk yield over the full first lactation. All data for the survival analysis of cows in 17 herds, before and after the change from CMS to AMS, were extracted from the SYMLEK official milk recording system managed by the Polish Federation of Cattle Breeders and Dairy Farmers.

The animal material under study, due to the statistical analyses performed for survival to a certain lactation, was grouped according to the following criteria (factors): milking system (MS), first calving season (CS), age at first calving (AFC), ease of first calving (CE), birth of a dead calf at first calving (DC), milk yield for full first lactation (MY) and herd (H) (Table 2).

Table 2. Distribution of cow survival to second (SL2), third (SL3) and fourth (SL4) lactation

\begin{tabular}{|c|c|c|c|c|c|}
\hline Factor & Level & $\mathrm{N}$ & SL2 & SL3 & SL4 \\
\hline 1 & 2 & 3 & 4 & 5 & 6 \\
\hline \multirow[t]{2}{*}{ Milking system } & CMS & 2734 & 82.221 & 77.491 & 48.171 \\
\hline & AMS & 3627 & 78.361 & 66.421 & 34.841 \\
\hline \multirow[t]{4}{*}{ Calving season } & Spring & 1525 & 79.931 & 70.251 & 39.871 \\
\hline & Summer & 1390 & 80.581 & 70.961 & 38.501 \\
\hline & Autumn & 1555 & 81.481 & 71.951 & 41.601 \\
\hline & Winter & 1891 & 78.481 & 72.651 & 42.611 \\
\hline \multicolumn{2}{|c|}{ Age at first calving (mths.) $\leq 24$} & 1509 & 83.371 & 73.091 & 43.141 \\
\hline & $>24 \leq 26$ & 2102 & 82.301 & 72.151 & 41.761 \\
\hline & $>26 \leq 28$ & 1287 & 79.491 & 71.931 & 40.301 \\
\hline & $>28$ & 1463 & 73.751 & 68.351 & 36.901 \\
\hline \multirow[t]{2}{*}{ Calving ease } & Easy & 1680 & 82.501 & 74.891 & 45.181 \\
\hline & Difficult & 4681 & 79.131 & 70.281 & 39.191 \\
\hline \multirow[t]{2}{*}{ Birth of a dead calf } & No & 5944 & 80.271 & 71.121 & 40.281 \\
\hline & Yes & 417 & 76.501 & 77.851 & 48.361 \\
\hline \multirow[t]{5}{*}{ Milk yield (kg) } & $\leq 6,000$ & 537 & & 75.051 & 44.051 \\
\hline & $6,001-8,000$ & 951 & & 74.971 & 48.181 \\
\hline & $8,001-10,000$ & 1349 & & 72.281 & 42.501 \\
\hline & $10,001-12,000$ & 1064 & & 72.271 & 39.671 \\
\hline & $>12,000$ & 957 & & 64.261 & 30.251 \\
\hline \multirow[t]{3}{*}{ Herd } & A & 239 & 83.681 & 64.401 & 33.951 \\
\hline & B & 123 & 91.061 & 72.971 & 42.161 \\
\hline & $\mathrm{C}$ & 237 & 80.171 & 67.351 & 31.971 \\
\hline
\end{tabular}


Table 2 - contd.

\begin{tabular}{c|c|c|c|c|c}
\hline 1 & 2 & 3 & 4 & 5 & 6 \\
\hline & D & 215 & 80.931 & 83.531 & 54.201 \\
& E & 764 & 87.831 & 83.861 & 61.571 \\
& F & 198 & 83.331 & 75.611 & 51.411 \\
& G & 331 & 76.441 & 64.521 & 30.431 \\
& H & 237 & 82.281 & 50.791 & 19.771 \\
& I & 477 & 92.661 & 85.121 & 61.081 \\
& J & 323 & 72.141 & 65.771 & 37.821 \\
& K & 128 & 79.691 & 73.171 & 45.311 \\
& L & 569 & 77.681 & 59.721 & 28.611 \\
& M & 190 & 78.421 & 67.791 & 31.501 \\
& N & 240 & 86.671 & 67.011 & 37.951 \\
& O & 629 & 69.481 & 75.971 & 42.251 \\
& P & 270 & 78.521 & 77.841 & 38.261 \\
& Z & 1191 & 75.991 & 66.821 & 33.251 \\
& N & 6361 & 50901 & 34751 & 16251 \\
& $\%$ & 100.00 & 80.021 & 54.631 & 25.551 \\
& $\%$ & 100.00 & & 68.272 & 31.922 \\
\hline
\end{tabular}

${ }^{1}$ proportion of heifers that calved and survived to second (SL2), third (SL3) and fourth lactation (SL4). ${ }^{2}$ proportion of second calvers (5090 cows) surviving to third (SL3) and fourth lactation (SL4).

AMS - automatic milking system; CMS - conventional milking system.

The test group was divided according to MS based on the following scheme:

- CMS (2734 cows) - dates of successive calving and culling date < AMS implementation date,

- AMS (3627 cows) - dates of successive calving and culling date > AMS implementation date.

The performed study disregarded those groups in which cows started the monitored production/reproduction cycles in CMS and continued them in AMS, as well as those cows that exited the herd through sales for further breeding.

Four seasons of calving were considered: SG - spring (March to May), SR summer (June to August), AN - autumn (September to November) and WR - winter (December to February). In terms of the next data grouping criterion - AFC, the following 4 classes were identified: (=<24 mths.), (24-26 mths.), (26-28 mths.), ( $>28 \mathrm{mths}$.). In terms of calving ease, cows were classified as those with unassisted delivery or requiring minor human assistance ( $\mathrm{E}$ - easy) and cows requiring major human assistance ( $\mathrm{D}$ - difficult) (dystocia, requiring veterinary attendance, Caesarean section). According to the next division criterion, primiparous cows that gave birth to live or dead calves were identified. Furthermore, 5 classes were recognized in terms of milk yield for the full first lactation $(=<6,000 \mathrm{~kg}, 6,001-8,000 \mathrm{~kg}, 8,001-$ $10,000 \mathrm{~kg}, 10,001-12,000 \mathrm{~kg},>12,000 \mathrm{~kg}$ ). For the purposes of statistical analysis, 
the herds were designated A to P and Z letters (Table 2). The most common classification factor in linear models describing variation in production traits of cattle is year of calving. However, it was excluded from statistical analyses because of its close association with the year AMS was introduced.

Multiple logistic regression was used to show factors statistically associated with SL2, SL3 and SL4. To this end, the following model was used:

$$
P\left(Y=1 \mid x_{1}, x_{2}, \ldots x_{k}\right)=\frac{e^{\left(a_{0}+\sum_{i=1}^{k} a_{i} x_{i}\right)}}{1+e^{\left(a\left(a_{0}+\sum_{i=1}^{k} a_{i} x_{i}\right)\right.}}
$$

where:

$P\left(Y=1 \mid x_{1}, x_{2}, \ldots x_{k}\right)$ - probability of the cow surviving to the second, third or fourth lactation,

$x_{1}, x_{2}, \ldots x_{k}$ - explanatory variables: MS, CS, AFC, CE, DC, H, H×MS, MY (MY was included for SL3 and SL4, excluded for SL2),

$a_{0}$ - intercept,

$a_{i}=1,2, \ldots \mathrm{k}-$ coefficients of regression associated to the explanatory variables,

$e-$ the base of the natural logarithm.

Significance of the regression coefficients was assessed with the Wald test (SAS Institute Inc., 2014). Quality of the generated models was judged by an area under (AUC) the ROC curve.

In the next step of logistic regression analysis, the odds ratios (OR) were estimated. Designing OR, it was necessary to indicate the so-called reference (base) group. Therefore, the following reference groups were indicated in the studies, depending on the factor: MS - CMS, AFC - >28 mths., CS - winter, CE - easy calving, DC live calf, $\mathrm{MY}-\leq 6,000 \mathrm{~kg}$, herd $-\mathrm{Z}$. Because OR is determined based on the sample population, it was necessary to introduce a measure of estimation $-95 \%$ confidence intervals.

\section{Culling reasons during first three lactations}

In the next step of research, the distribution of culling reasons for first (1271 cows), second (1615 cows) and third lactation cows (1850 cows) was analysed separately and in combination throughout this period (4736 cows), depending on the milking system (CMS, AMS). To this end, all the cows from the earlier research stage which did not survive to the second, third and fourth lactation, were accounted for. The following culling reasons were identified: udder diseases, low fertility (infertility and reproductive disorders), locomotor diseases, low milk yield, other diseases (metabolic, digestive and respiratory diseases), accidents and chance events. The statistical analysis of the culling reasons was performed by means of $\chi^{2}$ test.

All the statistical analyses were performed using the FREQ and LOGISTIC procedures of SAS (SAS Institute Inc., 2014). 


\section{Results}

\section{Cows survival to second, third and fourth lactation}

The primiparous cows calved at an average age of 26.5 months and produced $9791 \mathrm{~kg}$ of milk in the first lactation (Table 3). When considering the above parameters in terms of the milking system, it was established that cows from AMS barns first calved around 1 month earlier and their first lactation milk yield was $1821 \mathrm{~kg}$ higher compared to their age mates in CMS barns (Table 3). It was also observed that $80.02 \%$ of the calved heifers stayed in the herd until the second, $54.63 \%$ until third and $25.55 \%$ until fourth lactation (Table 2). In turn, $68.27 \%$ of second calvers calved for the third time, and $31.92 \%$ for the fourth time. The average number of completed lactations of the tested cows (disregarding the fact that they could be retained for further breeding) exceeded 2.66.

Table 3. Descriptive statistics of age at first calving and milk yield in full first lactation

\begin{tabular}{l|c|c|c|c|c|c|c}
\hline \multicolumn{1}{c|}{ Variable } & $\begin{array}{c}\text { Milking } \\
\text { system }\end{array}$ & $\mathrm{N}$ & $\begin{array}{c}\text { Lower } \\
\text { quartile }\end{array}$ & Median & $\begin{array}{c}\text { Upper } \\
\text { quartile }\end{array}$ & Mean & $\begin{array}{c}\text { Standard } \\
\text { deviation }\end{array}$ \\
\hline Age at first calving (mths.) & CMS & 2.734 & 24.4 & 26.1 & 28.8 & 27.0 & 3.8 \\
Milk yield (kg) & & 2.466 & 6.585 & 8.558 & 10.557 & 8.771 & 3.043 \\
Age at first calving (mths.) & AMS & 3.627 & 23.9 & 25.1 & 27.1 & 26.1 & 3.7 \\
Milk yield (kg) & & 3.143 & 8.443 & 10.186 & 12.185 & 10.592 & 3.007 \\
Age at first calving (mths.) & Total & 6.361 & 24.1 & 25.5 & 27.8 & 26.5 & 3.8 \\
Milk yield (kg) & & 5.609 & 7679 & 9528 & 11555 & 9791 & 3.155 \\
\hline
\end{tabular}

AMS - automatic milking system; CMS - conventional milking system.

Statistical analysis of SL2-SL4 was performed using multiple logistic regression. The calculated area under the ROC curve (AUC) ranged from 0.6537 to 0.7078 according to survival to next lactation, which indicates moderate prognostic value of the constructed models. Multiple logistic regression showed that change in the milking system had a highly significant effect on SL2 and SL3 (Table 4). The odds of survival (OR) of primiparous cows that were milked in AMS barns was lower by $27.8 \%$ to second lactation and by $31.0 \%$ to third lactation compared to the CMS period (Table 5). When additionally analysing survival percentage of the cows (Table 2) depending on the milking system, it was noted that in the CMS, $82.22 \%$ of primiparous cows survived to second lactation, and $77.49 \%$ and $48.17 \%$ of them calved for the third and fourth time, respectively (Table 2). In the case of the cows from AMS barns, these parameters were lower by $3.86,11.07$ and 13.33 p.p., respectively.

The logistic regression analysis revealed no statistically significant effect of calving season on SL2, SL3 and SL4 (Table 4). As a consequence, the odds of survival (OR) for spring, summer and autumn compared to winter calving cows varied within narrow limits close to unity (Table 5). Similar values were also noted for the percentage of cows that calved in different seasons and survived to second, third and fourth lactations in the following ranges: SL2 - 78.48-81.48\%, SL3 - 70.25-72.65\%, SL4 $-38.50-42.61 \%$ (Table 2). 
Table 4. Significance of variables ( $\mathrm{P}$ - Probability) included in the logistic regression model

\begin{tabular}{|c|c|c|c|c|c|c|}
\hline \multirow{2}{*}{ Effect } & \multicolumn{2}{|c|}{$\begin{array}{l}\text { Survival to second } \\
\text { lactation (SL2) }\end{array}$} & \multicolumn{2}{|c|}{$\begin{array}{l}\text { Survival to third } \\
\text { lactation (SL3) }\end{array}$} & \multicolumn{2}{|c|}{$\begin{array}{l}\text { Survival to fourth } \\
\text { lactation (SL4) }\end{array}$} \\
\hline & Wald test & $\mathrm{P}$ & Wald test & $\mathrm{P}$ & Wald test & $\mathrm{P}$ \\
\hline Milking system & 30.9391 & $<.0001$ & 51.2583 & $<.0001$ & 0.0140 & 0.9057 \\
\hline Calving season & 6.0372 & 0.1098 & 0.6937 & 0.8747 & 1.6124 & 0.6566 \\
\hline Age at first calving & 28.6074 & $<.0001$ & 8.4745 & 0.0372 & 7.5105 & 0.0573 \\
\hline Calving ease & 0.0329 & 0.8561 & 1.7643 & 0.1841 & 2.5774 & 0.1084 \\
\hline Birth of a dead calf & 9.1341 & 0.0025 & 4.0215 & 0.0449 & 1.8857 & 0.1697 \\
\hline Milk yield & & & 13.5328 & 0.0089 & 43.9236 & $<.0001$ \\
\hline Herd & 144.9565 & $<.0001$ & 125.3639 & $<.0001$ & 168.9376 & $<.0001$ \\
\hline Herd $\times$ Milking system & 52.0835 & $<.0001$ & 68.2019 & $<.0001$ & 100.8571 & $<.0001$ \\
\hline $\begin{array}{l}\text { Area under ROC curve } \\
(95 \% \text { confidence interval) }\end{array}$ & $\begin{array}{r}0.6 \\
(0.6372\end{array}$ & $\begin{array}{l}7 \\
6702)\end{array}$ & $\begin{array}{r}0.6 \\
(0.6621\end{array}$ & $\begin{array}{l}37 \\
.6952)\end{array}$ & $\begin{array}{r}0 . \\
(0.6917\end{array}$ & $\begin{array}{l}8 \\
7239)\end{array}$ \\
\hline
\end{tabular}

Our study showed that AFC had a significant effect on SL2 and SL3 (Table 4). Earlier calving primiparous cows had greater odds of surviving to second, third and fourth lactation compared to later calving cows ( $>28 \mathrm{mths}$.) (Table 5). Among others, the odds of survival to second lactation for cows calving before $24 \mathrm{mths}$. of age was 1.649 times greater than for cows calving after $28 \mathrm{mths}$. (Table 5). Similarly, the OR for SL3 and SL4 was 1.346 and 1.311, respectively. The favourable trends associated with early AFC, shown by OR for cow survival, are confirmed by the percentage values (for consecutive age groups of AFC): SL2 - 83.37-73.75\%, SL3 - 73.09-68.35 and SL4 - 43.14-36.90\% (Table 2).

Our study revealed no significant effect of the ease of first calving (CE) on SL2, SL3 and SL4 (Table 4). It is worth noting the observed favourable tendency for better survival in easy calvers (Tables 2 and 5). This is evidenced by the OR - the odds of survival of these cows, depending on consecutive lactation, was higher by 1.7 to $17.4 \%$ compared to difficult calvers in first lactation (Table 5). This tendency is confirmed by differences in survival structure between easy and difficult calvers, which ranged from 3.37 (SL2) to 5.99 p.p. (SL4) (Table 2).

The regression analysis showed a significant effect of the birth of a live/dead calf on SL2 and SL3 (Table 4). The birth of a live calf increased the heifer's odds of survival to second lactation by 1.468 compared to the birth of a dead calf (Table 5). An opposite trend was observed for SL3 and SL4 - heifers that gave birth to a dead calf and calved for the second time had greater odds of calving the next time, by 26.3 and $18.1 \%$ (Table 5); this was also reflected in the survival structure presented in Table 2.

The statistical analysis showed a highly significant effect of MY on SL3 and SL4 (Table 4). Considering the determined OR, it was observed that primiparous cows with a full lactation milk yield from 6001 to $8000 \mathrm{~kg}$, compared to those producing below $6000 \mathrm{~kg}$, had a 1.156 -fold $(\mathrm{P}>0.05)$ and 1.214 -fold $(\mathrm{P} \leq 0.01)$ greater odds of 
surviving to the second and third lactation, respectively. In turn, the odds of survival of the cows yielding more than $12,000 \mathrm{~kg}$ of milk, compared to the least productive group, was highly significantly smaller, by $19.9 \%$ (SL3) and 45.9\% (SL4), respectively (Table 5). A similar tendency for the effect of first lactation milk yield on SL3 and SL4 was observed when analysing survival percentage depending on the milk yield level, as presented in Table 2.

The logistic regression analysis demonstrated that the statistical source of SL2, SL3 and SL4 variation was herd membership and its interaction with MS (Table 4). Depending on the herd, the proportion of cows surviving to the second lactation ranged from 69.48 (Herd O) to $92.66 \%$ (Herd I) (Table 2). Among the cows that calved for the second time, the proportion of cows surviving to the third and fourth lactation ranged from $50.79 \%$ (Herd $\mathrm{H}$ ) to $85.12 \%$ (Herd I) and from $19.77 \%$ (Herd H) to $61.57 \%$ (Herd E), respectively.

Due to the specific objective of the research, OR for the herd effect was not determined; we analysed OR resulting from the herd $\times$ milking system interaction included in the statistical model (Table 6, Figures 1-3). The OR values presented in Table 6 and Figures 1-3, show that the effect of changing the milking system on SL2, SL3 and SL4 was unfavourable in most herds, as evidenced by low values of OR and by the determined confidence interval endpoints for OR, which did not exceed " 1 ". A beneficial effect of changing the milking system (OR $>1)$ on SL2 was observed only in herds C, E, G (OR - 1.134-1.412), on SL3 in herds E, I (OR - 1.463-1.566), and on SL4 in herds E, G, I (1.276-2.391). Unfortunately, considering the wide ranges of confidence intervals for the above OR, an unambiguously beneficial effect of changing the milking system (OR and both endpoints of CI95\% $>1$ ) was proven only in herd I for SL4. In this herd, automatically milked second calvers had 2.391fold $(\mathrm{OR}>1)$ greater odds of surviving to fourth lactation compared to the cows that had been conventionally milked in the same barn.

\section{Culling reasons during first three lactations}

Regardless of the milking system (Table 7, col. "I-III"), the most frequent culling reasons were low fertility, followed by accidents and chance events, udder and locomotor diseases. The $\chi^{2}$ test showed a significant relationship between milking system and reasons for culling cows in the second lactation, third lactation, and in the entire period under study (first to third lactations) (Table 7).

Our study showed that as a result of the change from CMS to AMS in the barns, there increased the proportion of second lactation cows culled for locomotor diseases (by 2.51 p.p.), low milk yield (by 1.81 p.p.) and other diseases (4.23 p.p.). At the same time, there were decreases in proportion of cows culled for udder diseases (by 1.65 p.p.), low fertility (by 2.08 p.p.) and accidents and chance events (by 4.82 p.p.). When analysing culling reasons in the third lactation, it was observed that compared to CMS-milked cows, AMS cows were less frequently culled for low fertility (by 2.94 p.p.) and accidents and chance events (by 5.82 p.p.). This was paralleled in AMS by increased culling rates due to udder diseases (by 2.35 p.p.), locomotor diseases (by 0.51 p.p.), low milk yield (by 0.98 p.p.) and other diseases (by 4.90 p.p.). 


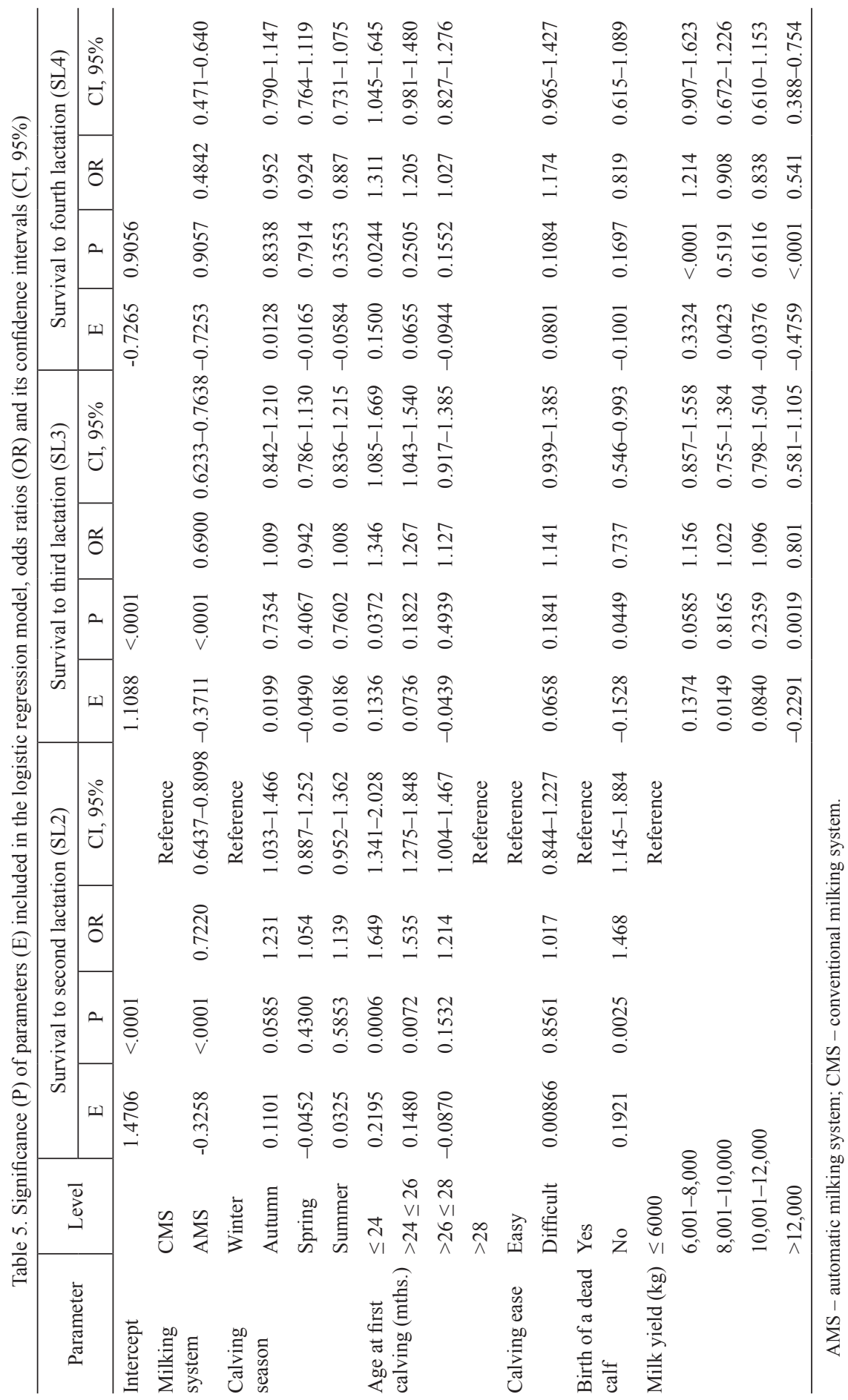


D. Piwczyński et al.

Table 6. Odds ratios (OR) and its confidence intervals (CI 95\%)

\begin{tabular}{l|c|c|c|c|c|c}
\hline \multirow{2}{*}{$\begin{array}{c}\text { Herd } \\
\text { AMS vs CMS }\end{array}$} & $\begin{array}{c}\text { Survival to second lactation } \\
\text { (SL2) }\end{array}$ & \multicolumn{2}{c|}{$\begin{array}{c}\text { Survival to third lactation } \\
\text { (SL3) }\end{array}$} & \multicolumn{2}{c}{$\begin{array}{c}\text { Survival to fourth lactation } \\
\text { (SL4) }\end{array}$} \\
\cline { 2 - 8 } & OR & CI, 95\% & OR & CI, 95\% & OR & CI, 95\% \\
\hline A & 0.345 & $0.144-0.825$ & 0.895 & $0.479-1.672$ & 0.591 & $0.299-1.168$ \\
B & 0.387 & $0.080-1.886$ & 0.418 & $0.160-1.095$ & 0.427 & $0.181-1.009$ \\
C & 1.134 & $0.592-2.172$ & 0.229 & $0.107-0.490$ & 0.244 & $0.104-0.573$ \\
D & 0.519 & $0.238-1.133$ & 0.397 & $0.151-1.046$ & 0.304 & $0.141-0.657$ \\
E & 1.288 & $0.832-1.993$ & 1.463 & $0.950-2.253$ & 1.276 & $0.875-1.861$ \\
F & 0.731 & $0.341-1.568$ & 0.500 & $0.240-1.043$ & 0.378 & $0.189-0.757$ \\
G & 1.412 & $0.835-2.387$ & 0.754 & $0.428-1.327$ & 1.045 & $0.539-2.028$ \\
H & 0.339 & $0.114-1.006$ & 0.080 & $0.030-0.217$ & 0.017 & $0.006-0.052$ \\
I & 0.204 & $0.061-0.680$ & 1.566 & $0.885-2.770$ & 2.391 & $1.247-4.583$ \\
J & 0.314 & $0.183-0.541$ & 0.521 & $0.295-0.920$ & 0.988 & $0.542-1.800$ \\
K & 0.832 & $0.281-2.460$ & 0.330 & $0.086-1.271$ & 0.665 & $0.196-2.252$ \\
L & 0.437 & $0.282-0.675$ & 0.331 & $0.219-0.502$ & 0.406 & $0.249-0.662$ \\
M & 0.207 & $0.026-1.618$ & 0.490 & $0.131-1.826$ & 0.527 & $0.156-1.777$ \\
N & 0.699 & $0.328-1.487$ & 0.858 & $0.466-1.578$ & 0.800 & $0.417-1.532$ \\
O & 0.319 & $0.206-0.493$ & 0.313 & $0.131-0.748$ & $<0.001$ & $<0.001->9999$ \\
P & 0.527 & $0.262-1.064$ & 0.410 & $0.186-0.906$ & 0.496 & $0.246-1.000$ \\
Z & 0.773 & $0.589-1.016$ & 0.458 & $0.341-0.616$ & 0.362 & $0.263-0.499$ \\
\hline
\end{tabular}

AMS - automatic milking system; CMS - conventional milking system.

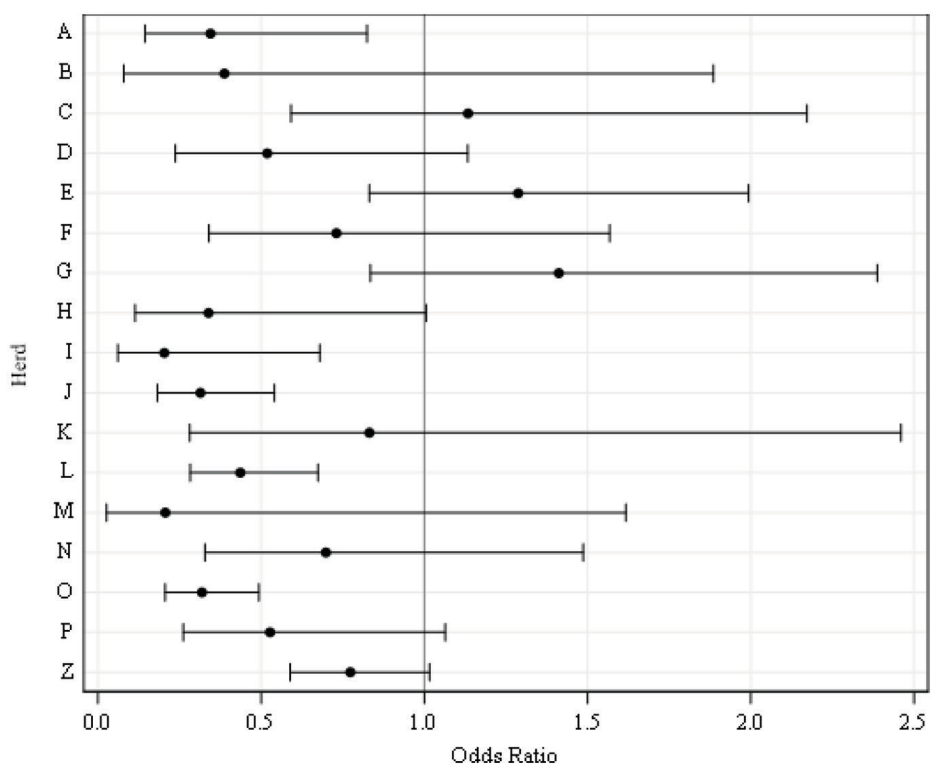

Figure 1. Effect of the change in the milking system on survival to second lactation (SP2) (odds ratio and its $95 \%$ confidence intervals) in the studied herds 


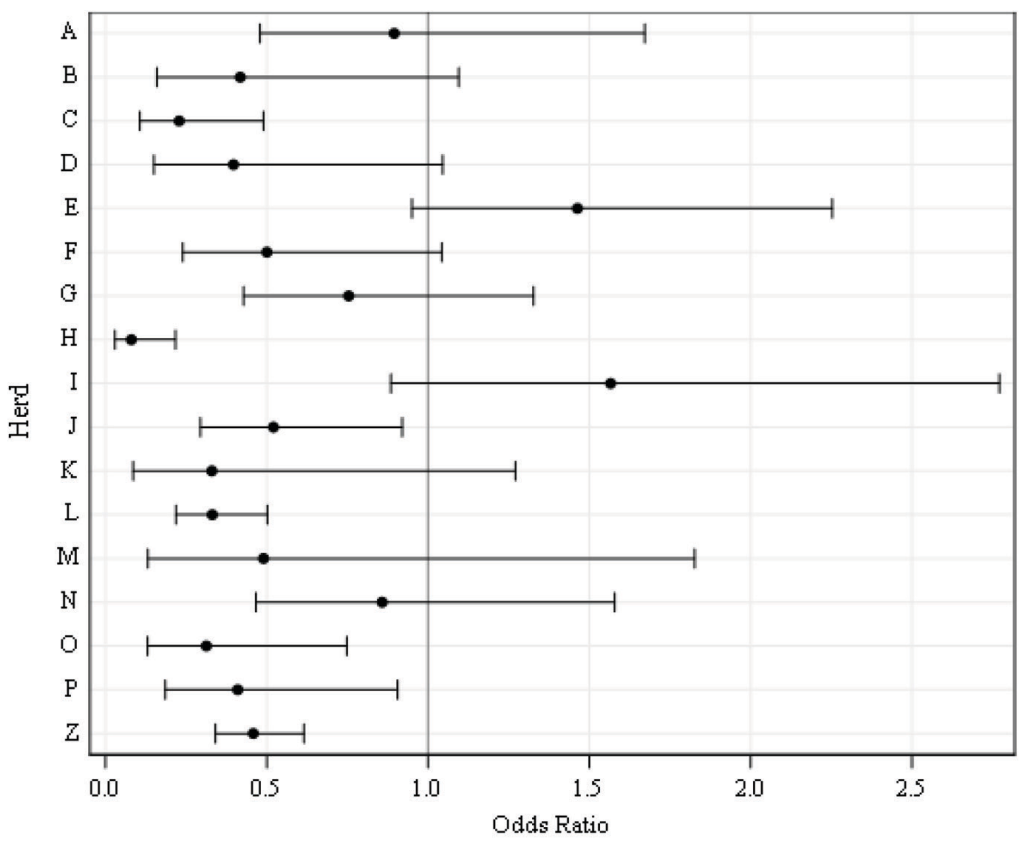

Figure 2. Effect of the change in the milking system on survival to third lactation (SP3) (odds ratio and its $95 \%$ confidence intervals) in the studied herds

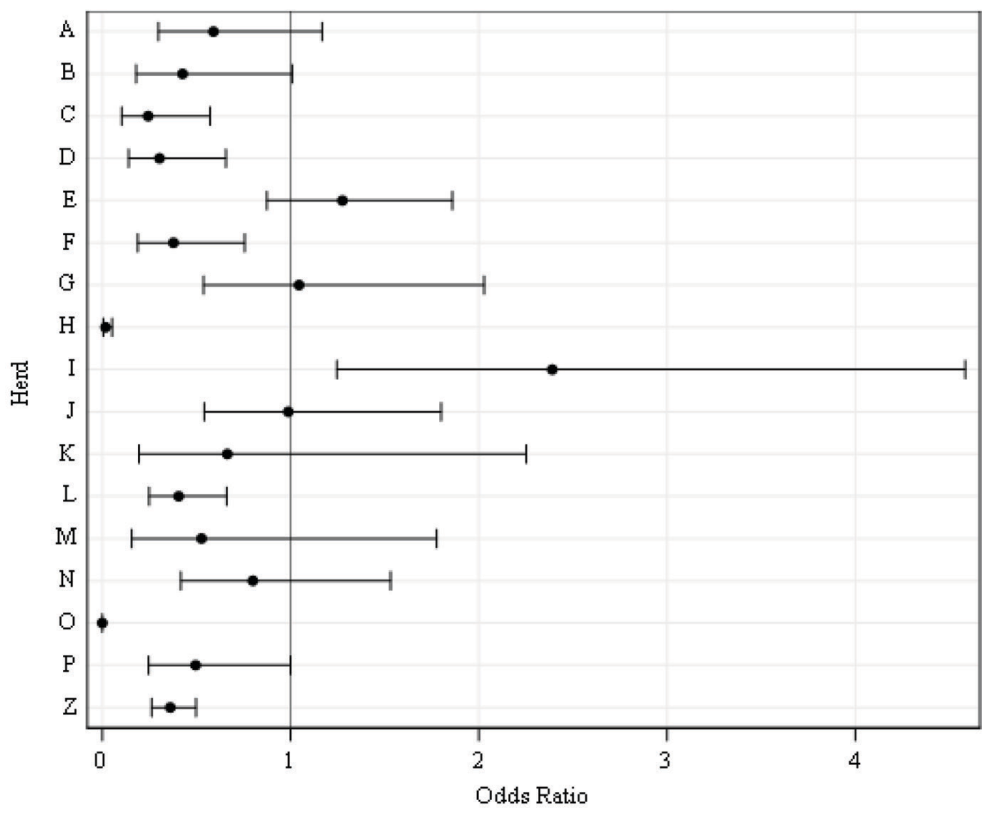

Figure 3. Effect of the change in the milking system on survival to fourth lactation (SP4) (odds ratio and its $95 \%$ confidence intervals) in the studied herds 
Table 7. Comparative analysis of culling reasons in different lactations according to the milking system $(\%)$

\begin{tabular}{|c|c|c|c|c|c|c|c|c|}
\hline \multirow{3}{*}{ Reason for culling } & \multicolumn{8}{|c|}{ Lactation } \\
\hline & \multicolumn{2}{|c|}{ I } & \multicolumn{2}{|c|}{ II } & \multicolumn{2}{|c|}{ III } & \multicolumn{2}{|c|}{ I-III } \\
\hline & CMS & AMS & CMS & AMS & CMS & AMS & CMS & AMS \\
\hline Udder diseases & 12.26 & 12.21 & 19.33 & 17.68 & 20.20 & 22.55 & 17.05 & 16.67 \\
\hline Low fertility & 38.90 & 33.93 & 37.30 & 35.22 & 34.85 & 31.91 & 37.14 & 33.90 \\
\hline Locomotor diseases & 13.95 & 13.88 & 11.69 & 14.20 & 15.66 & 16.17 & 13.70 & 14.55 \\
\hline Low milk yield & 1.48 & 2.57 & 0.22 & 2.03 & 0.51 & 1.49 & 0.76 & 2.12 \\
\hline Other diseases & 5.50 & 6.56 & 8.09 & 12.32 & 8.08 & 12.98 & 7.15 & 10.16 \\
\hline Accidents and chance events & 27.91 & 30.85 & 23.37 & 18.55 & 20.71 & 14.89 & 24.20 & 22.60 \\
\hline $\mathrm{P} \chi^{2}$ & \multicolumn{2}{|c|}{0.411} & \multicolumn{2}{|c|}{0.006} & \multicolumn{2}{|c|}{0.034} & \multicolumn{2}{|c|}{0.001} \\
\hline
\end{tabular}

AMS - automatic milking system; CMS - conventional milking system; $\mathrm{P} \chi^{2}$ - Probability.

Analysis of the reasons for culling in the first three lactations together showed that after the AMS system was introduced into the herds, the rate of culling increased for locomotor diseases (by 0.85 p.p.), low milk yield (1.36 p.p.) and other diseases (3.01 p.p.). It was also observed that the automation of milking reduced culling due to udder diseases by 0.37 p.p., low fertility by 3.24 p.p., and accidents and chance events by 1.60 p.p.

\section{Discussion}

\section{Cows survival to second, third and fourth lactation}

The Polish Federation of Cattle Breeders and Dairy Farmers (PFHBiPM, 2020) reports that in 2019, the number of completed lactations in cows in Poland averaged 2.93, varying from 2.85 to 3.25 according to the region of Poland. In our study, due to the relatively short history of automatic milking in Poland, cow survival was analysed only until the fourth lactation. The average number of completed lactations of the tested cows exceeded 2.66, which is similar to the result for the population of milk recorded cows in Poland (PFHBiPM, 2020).

The discrepant results of studies concerning the productive lifespan and functional longevity of dairy cows could be due to many factors (Sewalem et al., 2005; Sawa and Bogucki, 2010; Imbayarwo-Chikosi et al., 2017). Sewalem et al. (2005) stated the following as the main reasons for culling: herd, season of production, the annual change in herd size, age at first calving, stage of lactation, effect of milk, fat and protein yield and sire. In research by Beaudeau et al. (1995) culling reasons were: stage of lactation, age of cows, milk production level, poor reproductive parameters. Imbayarwo-Chikosi et al. (2017) showed that the following variables were differentiating the functional longevity of South African Holstein cows: region of the country, year of calving, AFC, lactation number, milk production level, herd 
size, and trends in herd size - decrease or increase. Zavadilová et al. (2011) reported functional longevity to decline with decreased body condition score of cows. Cows with deep udders had significantly lower functional survival compared to cows with shallow udders.

Our study showed that the proportion of the cows surviving to the second, third and fourth lactation (i.e. second, third and fourth calvers) was $79.55 \%, 54.63 \%$ and $25.55 \%$, respectively. In turn, in the study by Lubbers et al. (2000), who defined survival as completion of $n$ lactations by the cow (2.5), the proportion of cows that completed the second and third lactation was $77 \%$ and $56 \%$, respectively. In the study by Jairath et al. (1998), where survival to $n$ lactation was equal to non-culling of a cow before day 90 of $n$ lactation, the proportion of cows surviving to the second, third and fourth lactations was 77, 56 and 41\%, respectively. Our study demonstrated that $68.27 \%$ of the second calvers were third calvers, and $31.92 \%$ were fourth calvers. Analogous parameters in the study of Jairath et al. (1998) were higher at $71.4 \%$ and $66.7 \%$, respectively. In turn, Lubbers et al. (2000) stated that $73 \%$ of the cows that completed second lactation survived to third lactation in the herd. The discrepancies between our findings and those cited above probably result from different definitions of survival, as well as from distant periods of the experiments and different herd production levels. The intensive selection for milk production traits (milk yield, milk composition) had the negative effect of reducing cow longevity (Oltenacu and Broom, 2010).

Our study showed that milking automation had an adverse effect on survival of the cows to the second and third lactation. It should also be highlighted that herd membership and the herd $\times$ milking system interaction caused the greatest differences in cow survival out of all the variables included in the statistical analysis model. Analysis of the odds ratios for the MS effect indicates that in most herds, the transition from CMS to AMS had a negative impact on cow survival from the second to the fourth lactation. An unambiguously favourable effect of automation on cow survival was observed in a new barn with slatted floors and straw bedding in the lying area, where the number of milked cows was considerably increased. It is supposed that the unfavourable effect of milking automation could be due to the clear increase in milk production level resulting from the increased number of cows milked in the recorded herds. Tse et al. (2017) conducted a questionnaire survey of 217 cattle breeders who switched to the automatic milking system. After the change to the AMS, culling rate remained unchanged in 59\%, increased in 25\%, and decreased in almost $16 \%$ of the herds. The same authors also observed that the differences varied according to the milking system: they were small in herds with Lely AMS and higher in herds with DeLaval milking robots. Vukasinovic et al. (1997) concluded that the observed culling risk of cows may be due to intensive selection for milk yield traits.

Imbayarwo-Chikosi et al. (2017) observed that the risk of culling was lower in small herds (5-19 cows) and was highest in shrinking herds. Our results agree with those of Sewalem et al. (2008), the annual change in herd size was associated with relatively higher risk of culling in shrinking herds compared with stable herds. In research by Sewalem et al. (2005) more culling was found in unsupervised herds than in supervised herds. 
In trying to explain the unfavourable effect of MS on SL observed in our study, it is worth noting that first lactation milk yield increased in 16 of the milk recorded herds (Table 1). Our study also showed best survival from second to fourth lactation for the cows that had produced up to $8000 \mathrm{~kg}$ of milk as first calvers. Considering the CMS barns and the average level of MY, it was observed that it did not exceed $6000 \mathrm{~kg}$ in two barns, ranged from 6001 to $8000 \mathrm{~kg}$ in four barns, ranged from 8001 to $10,000 \mathrm{~kg}$ in ten barns, and exceeded $10,000 \mathrm{~kg}$ of milk in one barn. For AMS, the corresponding numbers of the barns were $1,0,8$ and 8 . Another justification of the unfavourable trend in poorer survival of the tested cows is the changing size of the population - it considerably increased after transition to the automatic milking. In turn, Sewalem at al. (2005) showed that high fluctuations in herd size increase culling risk. Furthermore, Imbayarwo-Chikosi et al. (2017) observed that culling risk was lower in small herds.

Our study found no significant effect of calving season on survival of heifers to the second, third and fourth lactation. The fact that calving season had no significant effect on longevity was also reported by Kučević et al. (2020).

Januś et. al. (2017) highlight that AFC is one of the most important factors and has a significant impact on cows' lactational productivity, lifetime productivity, and on cows' age at each calving time. According to Sawa et al. (2019) AFC of cows should be between 22.1 and 26.0 months, this is connected with the approximately $24 \%$ higher lifetime milk production. AFC after 28 months causes a decrease in the first lactation MY and lifetime milk production, reduces the number of calvings, and increases culling rate due to low milk yield and udder diseases (Beaudeau et al., 1995; Sawa et al., 2019; Sewalem et al., 2005).

In Holstein-Friesian cattle, AFC $\leq 24$ months is considered as the optimal age to maximize production and to minimize the costs on heifers (Olechnowicz et al., 2016; Zavadilová and Štipková, 2013). This is completely in line with our study, which showed that the significant effect of AFC on cow survival persisted up to the third lactation, while the odds ratio (OR) of survival to second, third and fourth lactation $(\mathrm{P}>0.05)$ was always higher for cows that calved up to 28 months of age than for the reference group made up of the cows that calved beyond 28 months. We also observed a downward trend for OR, which corresponds with the results of ImbayarwoChikosi et al. (2017). Of special note is the highly significant and significant coefficient of random regression for the effect of AFC in the group of cows that calved up to 24 months of age, which means that this is the most favourable period for calving from the aspect of cow survival to the second to fourth lactation.

Our results are consistent with the analyses of Sherwin et al. (2016), who showed a negative relationship between AFC and survival of first lactation heifers, whereas the most favourable calving period was when the animal was aged between 23 and 24 months (reference group). With each successive month of calving, the OR values for culling, determined by logistic regression, increased by 1.19 to 1.71 (>30 mths.).

Many authors have reported that difficult calving adversely affects cow survival (Bicalho et. al., 2007; Reynen et al., 2015; De Vries et al., 2010). Reynen et al. (2015) showed that cows that had dystocia were almost 13 times more likely to be 
culled within 60 days of age compared to cows without calving-related problems. Beaudeau (1995) showed that the relative hazard ratio for cows requiring assistance was 1.2-fold higher than for easy calvers, and they also demonstrated that cows with late metritis or early abortion had poor survival. In the study by De Vries et al. (2010), hazards of culling increased for cows that had greater calving difficulty - depending on parity (1-3), cows with very difficult calving faced a 1.59 to 1.95 greater risk of culling compared to cows that had no problem calving. Our results failed to confirm the results cited above, which may be due to many objective reasons. In our study, we classified calving as either easy or difficult, which resulted from the need to harmonize the official 5-point scale, which had been in effect until 2006, and the 6-point scale that followed. Another argument for this classification was the highly varied structure of calvings, which allowed us to assume that the same calving process is classified differently in different herds. In our study, the effect of calving ease of heifers on their survival to second, third and fourth lactation was not significant, and the estimated OR varied between 1.017 and 1.174, which suggests indeed a favourable effect of difficult calving on cow survival. The trend observed in our study should be viewed with caution, because the confidence intervals of OR were wide and contained value "1", which means that in the general population difficult calving may also have a negative effect on cow survival. In trying to justify the results, it should also be noted that the analysis of SL3 and SL4 only considered the group of heifers that were second calvers.

Our study showed that the birth of a live calf highly significantly increased the odds of another calving of the heifer by 1.468 . This result is similar to that reported by Bicalho et al. (2007) - the culling risk of cows with stillbirths was 11.41-fold higher than for the birth of a live calf that survived the first $48 \mathrm{~h}$. It is surprising to note the results concerning the effect of DC on SL3 $(\mathrm{P}<0.05)$ and SL4 $(\mathrm{P}>0.05)-$ the odds of survival was 26.3 to $18.1 \%$ lower when a live calf compared to a dead calf was born. In trying to justify this result, it should be stressed that it concerned only the group of heifers that were second calvers. It was therefore observed that the second calvers which produced a dead calf at first calving, had better odds of survival to third and fourth calving than their age mates which produced a live calf.

Many studies have reported a significant effect of the milk yield level on cow longevity (Beaudeau, 1995; Imbayarwo-Chikosi et al., 2017). In research by Sewalem et al. (2005) MY was the most important factor influencing survival, and the hazard increased as the milk production of the cows decreased. The trend observed by Sewalem et al. (2005) was confirmed by Vukasinovic et al. (1997) and ImbayarwoChikosi et al. (2017). It is likely the result of a positive, moderate genetic correlation (0.50) between first lactation milk yield and survival to complete third, fourth and fifth lactations (Brotherstone et al., 1997). Our results partly agree with those cited above for we noted a highly significant effect of MY on SL3 and SL4. At the same time, based on the determined OR we observed that both low and high level of MY adversely affects cow survival. The most favourable effects in terms of SL3 and SL4 were observed for cows yielding from 6001 to $8000 \mathrm{~kg}$ of milk, and the least favourable $(\mathrm{P} \leq 0.01)$ for cows producing more than $12,000 \mathrm{~kg}$ of milk. Considering the group of highest producing cows, their odds of calving for the fourth time 
was around half $(\mathrm{OR}=0.541)$ smaller than in the group yielding less than $6000 \mathrm{~kg}$. Borkowska and Januś (2009) indicated that high first lactation milk yield may have a negative impact on the health of young animals and result in early culling from the herd.

\section{Culling reasons during first three lactations}

The literature on the subject largely supports our results in terms of the reasons for culling of cows. Ahlman et al. (2011) reported that main reason for culling cows in organic herds was poor udder health, whereas for cows in conventional herds it was low fertility. Our results agree with those of Pokorska et al. (2012), who reported that the main reasons for culling PHF cows were infertility (23.40\%) and udder diseases (16.13\%). Similar findings to ours were presented by Adamczyk et al. (2017), who found infertility and reproductive disorders to be the main causes of culling (51.1\%) PHF cows. Mastitis (udder diseases) was reported to be one of the principal reasons for early culling of cows from the herd by De Vliegher et al. $(2005,2012)$. Mastitis before the peak of lactation or during the dry period increased the risk (relative culling rate in first lactation, 1.3 and 4.0, respectively) (Beaudeau et al., 1995). These authors stated that recent years saw an increase in the number of animals culled for udder diseases and a decrease in the number of reproductive disorders, including infertility. De Vries and Marcondes (2020) emphasize that dairy farmers continue to cull cows for reasons related to poor health, failure to conceive or conformation problems prior to culling. A different distribution of culling reasons than ours was presented by Beaudeau et al. (1995) - being culled increased in older cows, in early and late stages of lactation, and in cows with low reproductive performance. According to Olechnowicz et al. (2016) culling of cows is significantly associated with the need for assisted calving, abortion and mastitis. Early studies of automatic milking systems (AMS) reported between 2001 and 2006, compared AMS with conventional milking systems (CMS). Observations before and after the installation of an AMS showed that udder health deteriorated with the introduction of AMS. Researchers found higher numbers of new infections and higher mean SCC (Hovinen and Pyörälä, 2011). However, more recent studies with newer generation AMS, as well as improved barn design and management optimized for robot milking, showed no change in udder health and teat end condition, while in some cases, the introduction of AMS actually improved teat end condition (Jacobs and Siegford, 2012). There are significant differences in the management of udder health when comparing AMS to CMS. Cow movement, feeding systems and detection methods change when milking with an AMS. Milking frequency, milking interval, procedures for teat cleaning and teat dipping are all different compared to CMS. There is no longer visual oversight for ensuring adequately cleaned teats and clinical mastitis detection (Hovinen and Pyörälä, 2011). The mastitis detection methods have improved considerably in recent years and as robot milking systems are upgraded, udder health benefits. Managing lameness is especially crucial in AMS herds because of the (ideally) voluntary component of milking activity. At the cow level in AMS, lameness has been associated with reduced milk yield, reduced total and voluntary milking frequency, and greater daily lying time (Westin et al., 2016). 
The culling reasons reported by Pokorska et al. (2012) and Kern et al. (2016) include milk yield and the fat and protein content of the milk. In our study, the proportion of cows culled due to low milk production was low and did not exceed $3 \%$. Our study demonstrated that the distribution of culling reasons for CMS and AMS cows changed in successive lactations. A significant relationship was found between milking system and culling reasons in the second and third lactation and during the entire period from first to third lactation. It is interesting from the perspective of the aim of the present study that in AMS barns, with each successive lactation, there were increases in culling rate due to udder diseases, diseases of the locomotor system and other diseases, and decreases in culling rate due to low milk yield, partly in terms of low fertility and accidents and chance events. At the same time it should be noted that throughout the study, AMS cows compared to CMS cows were culled less frequently due to udder diseases and low fertility and other diseases, and more often because of locomotor diseases. Therefore, in barns equipped with the automatic milking system it is necessary to implement sound mastitis prevention programmes while taking good care of claw hygiene and flooring hygiene.

\section{Conclusions}

In our study, we showed a significant effect of milking system, age at first calving, and birth of a dead calf on SL2 and SL3. A significant effect of herd and the milking system $\times$ herd interaction was also found for SL2, SL3 and SL4. The level of first lactation milk yield caused significant differences in SL3 and SL4. Cows used in CMS barns showed significantly better survival to second and third lactation compared to cows milked in the AMS. At the same time it was shown that the magnitude of this effect was determined by herd membership. In most herds, the effect of milking automation was unfavourable. A distinctly positive effect of milking automation on cow survival was noted in only one herd - it was a new barn with a considerably expanded number of milked cows, where the lying area was covered with straw. It is supposed that the unfavourable effect of milking automation could be due to the marked increase in milk production level per lactation and the considerably increased number of milked cows.

Analysis of the reasons for culling in the first three lactations together showed that after the AMS system was introduced into the herds, the rate of culling increased for locomotor diseases, low milk yield and other diseases, at the same time reduced culling due to udder diseases, low fertility, and accidents and chance events.

\section{References}

A d a mczyk K., Szarek J., Majewska A., Jagusiak W., Gil Z. (2017). Factors affecting longevity of cows with high share of Polish local breeds' genes. Anim. Sci. Pap. Rep., 35: 35-46.

A hl man T., B erglund B., Rydhmer L., Strandberg E. (2011). Culling reasons in organic and conventional dairy herds and genotype by environment interaction for longevity. J. Dairy Sci., 94: $1568-1575$.

B e a u deau F., Ducroc q V., Fourichon C., S e e ger s H. (1995). Effect of disease on length of productive life of French Holstein dairy cows assessed by survival analysis. J. Dairy Sci., 78 : $103-117$. 
B icalho R.C., Galvão K.N., Cheong S.H., Gilbert R.O., Warnick L.D., Guard C.L. (2007). Effect of stillbirths on dam survival and reproduction performance in Holstein dairy. J. Dairy Sci., 90: 2797-2803.

B o r k ow s k a D., J a n u ś E. (2009).Yield of primiparous cows and their lifetime productivity (in Polish). Rocz. Nauk. PTZ, 5: 87-94.

B rotherst on e S., Ve e r k a m p R.F., Hill W.G. (1997). Genetic parameters for a simple predictor of the lifespan of Holstein-Friesian dairy cattle and its relationship to production. Anim. Sci., 65: 31-37.

De Vliegher S., B arkema H., Stryhn H., Opsomer G., de Kruif A. (2005). Impact of early lactation somatic cell count in heifers on milk yield over the first lactation. J. Dairy Sci., 88: 938-947.

D e Vliegher S., F ox L., P i e pers S., M c D o u g a 11 S., B a r k e m a H. (2012). Invited review: Mastitis in dairy heifers: Nature of the disease, potential impact, prevention, and control. J. Dairy Sci., 95: 1025-1040.

D e Vries A., M a r c o n d e s M.I. (2020). Overview of factors affecting productive lifespan of dairy cows. Animal, 14: 155-164.

D e Vries A., O ls o n J.D., P in e d o P.J. (2010). Reproductive risk factors for culling and productive life in large dairy herds in the eastern United States between 2001 and 2006. J. Dairy Sci., 93: 613-623.

Gygax L., Neuffer I., Kaufmann C., Hauser R., We chsler B. (2007). Comparison of functional aspects in two automatic milking systems and auto-tandem milking parlors. J. Dairy Sci., 90: 4265-4274.

Hopster H., Bruckmaier R., Van der Werf J., Korte S., Macuhova J., Korte- B ouws G., Van Reen en C. (2002). Stress responses during milking; comparing conventional and automatic milking in primiparous dairy cows. J. Dairy Sci., 85: 3206-3216.

H o vi n e n M., P y ör älä S. (2011). Invited review: udder health of dairy cows in automatic milking. J. Dairy Sci., 94: 547-562.

I m b a y a rwo-Chikos i V.E., Ducroc q V., B anga C.B., Ha li man i T.E., van Wyk J.B., Ma i w a s h A., D z a m a K. (2017). Estimation of genetic parameters for functional longevity in the South African Holstein cattle using a piecewise Weibull proportional hazards model. J. Anim. Breed. Genet., 134: 364-372.

J a c o b s J.A., S i e g ford J.M. (2012). Invited review: The impact of automatic milking systems on dairy cow management, behaviour, health, and welfare. J. Dairy Sci., 95: 2227-2247.

J a i r a th L.J.C.M., D e k k e r s J.C.M., S c ha e ffer L.R., L i u Z., B u rn s i d e E.B., K ols t a d B. (1998). Genetic evaluation for herd life in Canada. J. Dairy Sci., 81: 550-562.

J a nuś E., S a b lik P., S t a n e k P., Z ółk i e w s ki P. (2017). Relationship between age at first calving and selected features of the lifetime performance of Montbéliarde cows. Acta Sci. Pol. Zoot., 16: $45-52$.

Kern E., Cobuci J., Cost a C., Ducrocq V. (2016). Survival analysis of productive life in Brazilian Holstein using a piecewise Weibull proportional hazard model. Livest. Sci., 185: 89-96.

Kučević D., Trivunović S., Šoronja Ž., Janković D., S t anojević D., Dedović R., P a p o vi ć T. (2020). Association between age at first calving and milk production in first lactation on longevity traits in Holstein cows. Biotechnol. Anim. Husb., 36: 27-35.

Lubbers R., B rotherstone S., Ducrocq V.P., Vis s cher P.M. (2000). A comparison of a linear and proportional hazards approach to analyse discrete longevity data in dairy cows. Anim. Sci., 70: 197-206.

Olechnowicz J., Kneblewski P., Jaśkowski J.M., Włodarek J. (2016). Effect of selected factors on longevity in cattle: a review. J. Anim. Plant Sci., 26: 1533-1541.

Olten a c u P., B room D. (2010). The impact of genetic selection for increased milk yield on the welfare of dairy cows. Anim. Welf., 19: 39-49.

Or p in P.G., E s s l e m on t R.J. (2010). Culling and wastage in dairy herds: an update on incidence and economic impact in dairy herds in the UK. Cattle Pract., 18: 163-172.

Pelt M.L., Meuw is s en T.H.E., De Jong G., Veerkamp R.F. (2015). Genetic analysis of longevity in Dutch dairy cattle using random regression. J. Dairy Sci., 98: 4117-4130.

PFHBiPM (2020). Polish Federation of Cattle Breeders and Dairy Farmers. The results of breeding value of cattle. Retrieved from http://www.pfhb.home.pl. Access: 25.03.2020. 
Piwczyński D., Brzozowski M., Sitkowska B. (2020). The impact of the installation of an automatic milking system on female fertility traits in Holstein-Friesian cows. Livest. Sci. 240: 104140.

P ok orska J., Kulaj D., Ormian M. (2012). Reasons for culling of Polish HF Black-and-White cows, managed in a high production farm. Sci. Ann. PSAP, 8: 17-24.

R e y n e n J.L., K e 1 t o n D.F., L e B l a n c S.J., N e w b y N.C., D u ffi e ld T.F. (2015). Factors associated with survival in the herd for dairy cows following surgery to correct left displaced abomasum. J. Dairy Sci., 98: 3806-3813.

S a w a A., B og u c ki M. (2010). Effect of some factors on cow longevity. Arch. Anim. Breed., 53: $403-414$.

S a w a A., S i a t k a K., K ręż e l-C z o p e k S. (2019). Effect of age at first calving on first lactation milk yield, lifetime milk production and longevity of cows. Ann. Anim. Sci., 19: 189-200.

S e wa l e m A., K is te maker G.J., D u croc q V., Van D oorma a B.J. (2005). Genetic analysis of herd life in Canadian dairy cattle on a lactation basis using a Weibull proportional hazards model. J. Dairy Sci., 88: 368-375.

Sewalem A., Miglior F., Kistemaker G., Sullivan P., Van Doormaal B. (2008). Relationship between reproduction traits and functional longevity in Canadian dairy cattle. J. Dairy Sci., 91: 1660-1668.

$\mathrm{S}$ habalin a T., Y in T., K ön ig S. (2020). Influence of common health disorders on the length of productive life and stayability in German Holstein cows. J. Dairy Sci., 103: 583-596.

Sh erwin V., Hud s o n C., Henders on A., Green M. (2016). The association between age at first calving and survival of first lactation heifers within dairy herds. Animal, 10: 1877-1882.

S i a t k a K., S a w a A., Kręż e l- C z o p e k S., B o g u c k i M. (2020). Longevity of Holstein-Friesian cows and some factors affecting their productive life - a review. Anim. Sci. Pap. Rep., 38: $107-116$.

Tremblay M., Hess J.P., Christenson B.M., McIntyre K.K., Smink B., van der K a m p A.J., de Jong L.G., Döpfer D. (2016). Factors associated with increased milk production for automatic milking systems. J. Dairy Sci., 99: 3824-3837.

Tse C., Barkema H., De Vries T., Rushen J., Pajor E. (2017). Effect of transitioning to automatic milking systems on producers' perceptions of farm management and cow health in the Canadian dairy industry. J. Dairy Sci., 100: 2404-2414.

Vukas in ovi c N., Moll J., Künzi N. (1997). Analysis of productive life in Swiss Brown cattle. J. Dairy Sci., 80: 2572-2579.

Westin R., Vaughan A., de Passillé A.M., De Vries T.J., Pajor E.A., Pellerin D., S i e g f ord J.M., Va s s e u r E., R u s h e n J. (2016). Lying times of lactating cows on dairy farms with automatic milking systems and the relation to lameness, leg lesions, and body condition score. J. Dairy Sci., 99: 551-561.

Z a v a di l o vá L., Š tí p k o vá M. (2013). Effect of age at first calving on longevity and fertility traits for Holstein cattle. Czech J. Anim. Sci., 58: 47-57.

Z a vadilová L, N ěm cová E., Š tí p k ová M. (2011). Effect of type traits on functional longevity of Czech Holstein cows estimated from a Cox proportional hazards model. J. Dairy Sci., 94: 4090-4099.

Received: 29 VIII 2020

Accepted: 26 I 2021 